Vol. 11 (4): 1007-1012 (2021)

\title{
ADAPTATION OF FARM ANIMALS TO HOUSING CONDITIONS
}

\author{
Lyudmila K. Buslovskaya $^{1^{*} \text {, Alexey Yu. Kovtunenko }}{ }^{1}$, Valery A. Cherkasov ${ }^{1}$

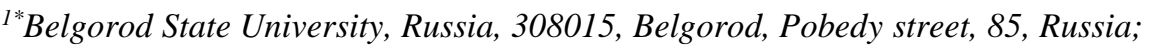 \\ *Corresponding Author Lyudmila K. Buslovskaya, e-mail: Buslovskaya@bsu.edu.ru;
}

Received August 2021; Accepted September 2021; Published October 2021;

DOI: https://doi.org/10.31407/ijees11.446

\begin{abstract}
The features of calves and chicken adaptation to new housing conditions, and to technological operations were studied in present work. It was found that the most serious stress factor for animals is transportation under conditions of high summer air temperatures. It is accompanied by regrouping, landing compaction, disruption of social contacts and leads to the organism adaptive mechanism stress. After transportation of calves to an industrial feeding complex, they revealed body and individual areas of skin surface temperature increase, stimulation of the cardiovascular and respiratory system functions, the heart rate increase by $17-25 \%$, respiratory rate increase by 38 $47 \%$, increase of total protein concentration in blood serum, the decrease in hematocrit, etc. Acid-base balance disorders of an acidotic nature appeared with a significant decrease in blood $\mathrm{pH}$, low values of buffer base concentration in the blood of both calves and chickens. After loading, transportation, and transplantation under conditions of summer heat, hens showed metabolic acidosis of the decompensated phase with a significant decrease in $\mathrm{pH}(7.27 \pm 0.07)$, a negative and very significant shift in buffer bases $(-16.7 \pm 5.9)$, and their deficiency $(12.1 \pm$ 3.1). After transportation of chickens in winter at the temperature of $-6{ }^{\circ} \mathrm{C}$, the violations of the acid-base balance in chicken blood appeared, but they were less pronounced. It was found that the adaptation of calves and chickens to transport stress is very slow, affects health and productivity, which must be taken into account in the practice of animal husbandry and poultry farming.
\end{abstract}

Key words: Stress, cattle, housing conditions, adaptation 